Research Article

\title{
Purification and Characterization of a New Lectin from Loach Skin Mucus
}

\author{
Peng-peng Sun $\mathbb{D}^{1,2}$ Yuan-yuan Ren, ${ }^{1,2}$ Jie Zheng $\mathbb{D}^{1,2}$ and Ai-jun $\mathrm{Hu} \mathbb{C}^{1,2}$ \\ ${ }^{1}$ State Key Laboratory of Food Nutrition and Safety, Tianjin University of Science \& Technology, Tianjin 300457, China \\ ${ }^{2}$ Laboratory of Food Nutrition and Safety, Ministry of Education, Tianjin University of Science \& Technology, \\ Tianjin 300457, China
}

Correspondence should be addressed to Jie Zheng; jane@tust.edu.cn and Ai-jun Hu; huaijun@tust.edu.cn

Received 5 January 2019; Revised 7 June 2019; Accepted 3 July 2019; Published 25 August 2019

Academic Editor: Angela Cardinali

Copyright (c) 2019 Peng-peng Sun et al. This is an open access article distributed under the Creative Commons Attribution License, which permits unrestricted use, distribution, and reproduction in any medium, provided the original work is properly cited.

Lectin from loach skin mucus plays an important role in pathogen defense. However, hardly can any paper relevant to the character of lectin from loach skin mucus be found in recent years. In this study, a kind of new lectin (LML), with a high hemagglutination activity of $166.23 \times 10^{3} \mathrm{HU} / \mathrm{mg}$, was successfully isolated and purified from loach skin mucus. LML was a kind of glycoprotein with a molecular weight of $245 \mathrm{kDa}$. Also, the monosaccharide composition suggested that its carbohydrate chain was composed of rhamnose, arabinose, xylose, mannose, glucose, and galactose with a molar ratio of $2.02: 11.66: 2.06: 1.00: 14.09$ : 6.00. Besides, LML depended on $\mathrm{Ca}^{2+}$ to induce hemagglutination and was strongly inhibited by D-lactose. The lectin exhibited powerful resistance to alkali and kept about $30 \%$ hemagglutination activity at $\mathrm{pH}$ 14.0, whereas its capacity of acid resistance was weak. The maximum hemagglutination activity of LML maintained at a temperature range from $20^{\circ} \mathrm{C}$ to $50^{\circ} \mathrm{C}$. Moreover, the structure of LML was preliminarily studied, indicating it contained abundant glutamic acid, histidine, and serine, and its secondary structure contained $\alpha$-helix (4.97\%), $\beta$-sheet (27.55\%), turns structure $(49.78 \%)$, and unordered structure $(17.70 \%)$.

\section{Introduction}

Loach (Misgurnus anguillicaudatus), a nutritious freshwater fish distributed in Asia, so-called ginseng of water, known as a traditional medicine for over 2000 years in Chinese pharmacopoeia, has attracted more and more attentions due to its high nutritional and pharmacological values. It has been reported that loach has important biological functions such as anti-inflammatory and used in the treatment of hepatitis and cancer $[1,2]$, and it contains various compounds such as antimicrobial peptide, hyaluronic acid, and taurine [3-5]. Moreover, loach could secrete important skin mucus as the first barrier in defense mechanism to protect itself from bacterial and parasitic infection in water [6]. Importantly, its skin mucus contains various bioactive constituents with a high medical value. For example, superoxide dismutase, polysaccharide, glycoprotein, and lectin were detected in loach skin mucus [7-10]. Especially, lectins existing in the mucus are of great importance and might play a critical role in pathogen defense [11]. Many kinds of lectins originating from animal skin mucus were detected and studied, especially in fish, such as windowpane flounder, Arabian Gulf catfish, conger eel, and kingklip [11]. Lectins, glycoprotein or protein of nonimmune origin, could agglutinate cells including erythrocytes, lymphocytes, and microbial cells or precipitate glycoconjugates through carbohydrate-specific binding sites [12]. Lectins are widely distributed in microorganisms, viruses, animals, and higher plants with different molecular weights, functions, and structures [13]. Thereinto, animal lectins could be classified into C-type (requiring $\mathrm{Ca}^{2+}$ for recognition), S-type (requiring free thiols for stability), P-type (recognizing Man-6$\mathrm{P})$, I-type (an immunoglobulin), heparin-binding proteins, and rhamnose-binding lectins according to the structure of CRD (carbohydrate recognition domain) [11, 14]. Previous research studies revealed that lectin had many functions such as protection, biological nitrogen fixation, mitogenesis, and immunomodulation [15-17]. Besides, researchers 
revealed that some kinds of lectin could serve as decoration of drug applied in pharmaceutical industry due to its sugar specificity, and this technology was expected to enhance absorption and bioavailability of poorly absorbable drugs [14]. However, these studies were usually focused on functional analysis or gene identification, and it was rare to explore the structural characterization and stability of animal lectin, especially lectin from fish skin mucus. Lectins from loach skin mucus (MAL-1 and MAL-2) were firstly detected by Goto-Nance et al. in 1995 [9]. Unfortunately, other papers relevant to loach mucus lectin have not been reported so far. Also, a great amount of skin mucus from loach was wasted during the course of transportation and processing, which triggered the insufferable stench and waste of resources. Therefore, the skin mucus of loach was studied in this paper, and a novel lectin (LML) was successfully isolated and purified from it. Our research was aimed at conducting the characterization of LML, which would provide theoretical foundation on comprehensive utilization of skin mucus from loach.

\section{Materials and Methods}

2.1. Materials and Chemicals. Live loaches were supplied by Hongteng aquatic products Co. Ltd. (Tianjin, China). Fresh rabbit erythrocytes were purchased from Naruizeng Biotechnology Co. Ltd. (Tianjin, China). Unless stated otherwise, all the chemicals and reagents were of analytical grade and purchased from Tianjin Chemical Reagent Co. Ltd. (Tianjin, China).

2.2. Collection of Loach Skin Mucus. $2000 \mathrm{~g}$ of live loaches with approximately the same size $(200 \pm 5 \mathrm{~g})$ were placed in a basin with $200 \mathrm{~mL}$ distilled water at room temperature for 10 min. During this period, external stimuli by operator's hands wearing disposable gloves was imposed on loaches to make them wriggle drastically. When plentiful mucus was produced on loach skin, loaches were removed one by one with their skin mucus dropped down to the container by the operator. Finally, the liquid remaining in the previous basin as well as the droppings in the container were collected, and then skin mucus of loaches were obtained. After centrifugation (Anke TGL-18kR, China) at $4,200 \times \mathrm{g}$ for $15 \mathrm{~min}$ at $4^{\circ} \mathrm{C}$, the supernatant was freeze-dried (Scientz FC-10A-E, China) to obtain fine mucus powder and stored at $-20^{\circ} \mathrm{C}$ until use.

2.3. Extraction and Purification of Lectin. $5 \mathrm{~g}$ of mucus powder was extracted with distilled water $(500 \mathrm{~mL})$ at $4^{\circ} \mathrm{C}$ for $2.5 \mathrm{~h}$, and then the extracts were centrifuged at $4,200 \times \mathrm{g}$ for $20 \mathrm{~min}\left(4^{\circ} \mathrm{C}\right)$. The supernatant was precipitated by ethanol (supernatant: ethanol $=1: 4, \mathrm{v} / \mathrm{v}$ ) for $24 \mathrm{~h}$ at $4^{\circ} \mathrm{C}$. After centrifugation at $4,200 \times \mathrm{g}$ for $20 \mathrm{~min}\left(4^{\circ} \mathrm{C}\right)$, the sediment was obtained and lyophilized as crude extract. The crude extract from loach skin mucus was purified by anion-exchange chromatography and gel filtration chromatography, and all purification steps were performed at $4^{\circ} \mathrm{C}$. The crude extract was dissolved in phosphate-buffered saline (PBS) $(20 \mathrm{mM}$,
$\mathrm{pH}$ 7.2) to make its concentration be $10 \mathrm{mg} / \mathrm{mL}$. Then, $5 \mathrm{~mL}$ of sample solution was loaded onto a DEAE-52 column $(\Phi 2.6 \mathrm{~cm} \times 20 \mathrm{~cm})$ after equilibrating with PBS $(20 \mathrm{mM}, \mathrm{pH}$ 7.2). The lectin solution was stepwise eluted by $0,0.3,0.5$, and $0.7 \mathrm{M} \cdot \mathrm{NaCl}$ solution $(250 \mathrm{~mL}$, mixed with $\mathrm{PBS})$ at a rate of 1 $\mathrm{mL} / \mathrm{min}$, and the eluent was collected automatically with 5 $\mathrm{mL}$ in each test tube. The fractions were determined at $280 \mathrm{~nm}$ using a spectrophotometer (Shimadzu UV-2550 PC, Japan). The main factions (D-0, D-1, D-2, and D-3) of crude extract were collected, dialyzed, and lyophilized for further purification. Gel filtration chromatography was used for the purification of the fraction D-3. The pretreated D-3 $(20 \mathrm{mg})$ was dissolved in $1 \mathrm{~mL}$ PBS $(20 \mathrm{mM}, \mathrm{pH} 7.2)$, loaded onto a Sephadex G200 column $(\Phi 1.0 \mathrm{~cm} \times 40 \mathrm{~cm})$ after equilibrating with PBS (20 mM, pH 7.2) at a flow rate of $0.3 \mathrm{~mL} / \mathrm{min}$, and the eluent was collected automatically with $2.4 \mathrm{~mL}$ in each test tube. The fractions were determined at $280 \mathrm{~nm}$, and the main fraction was collected, dialyzed, and lyophilized.

2.4. Determination of Protein and Carbohydrate Contents. Protein content was determined by the Bradford method [18], and bovine serum albumin was used as standard. Total carbohydrate content was measured by the phenol-sulfuric acid colorimetric method using glucose as the standard [19].

2.5. Hemagglutination Activity Assay. Erythrocyte suspensions $(2 \%, v / v)$ were prepared using rabbit erythrocytes in PBS solution (10 mM, pH 7.2) according to the method in the literature with some modification [20]. The mucus lectin samples were serially diluted with PBS solution $(50 \mu \mathrm{l})$, and then $2 \%$ erythrocyte suspension $(50 \mu \mathrm{l})$ was added in 96 -well Falcon $\mathrm{V}$-shaped microtiter plates. When the solution of the highest dilution times made a homogeneous suspension of agglutinated erythrocytes in the well bottom after incubation at room temperature for $1 \mathrm{~h}$, hemagglutination activity was evaluated. One unit of hemagglutination activity was defined as the lowest amount of lectin in the well causing agglutination (equation (1)). The hemagglutination activity (HU/ $\mathrm{mg}$ ) was defined as the number of hemagglutination titer per mg protein. The experimental procedures were approved (Permit no. 2018040201) by the Institutional Ethics Committee for Animals.

$$
\text { Hemagglutination activity }\left(\times 10^{3} \frac{\mathrm{HU}}{\mathrm{mg}}\right)=\frac{2^{n}}{V \times C} \times 10^{-3} \text {, }
$$

where $n$ was the maximum wells causing agglutination; $V$ was the volume of sample added to the well, $\mathrm{mL}$; $C$ was the concentration of protein in sample, $\mathrm{mg} / \mathrm{mL}$.

\subsection{Characterization of $L M L$}

\subsubsection{Analysis of Molecular Weight and Purity}

(1) SDS-PAGE. The molecular weight and purity of lectin was determined by SDS-PAGE and high-performance gel- 
permeation chromatography (HP-GPC), respectively. Samples were electrophoresed using the procedure of Laemmli [21]. Dissociation and reduction of LML was performed by heating for $5 \mathrm{~min}$ at $100^{\circ} \mathrm{C}$ with $2 \%(\mathrm{w} / \mathrm{v})$ SDS and $1 \%(\mathrm{v} / \mathrm{v}) 2$-mercaptoethanol $(\mathrm{v} / \mathrm{v})$. The electrophoretic procedure was performed using a Mini-Protean III electrophoretic system (Bio-Rad, USA) under a constant voltage $(80 \mathrm{~V})$, and rainbow prestained markers $(11 \mathrm{kDa}-245 \mathrm{kDa})$ (Beijing Solarbio Science and Technology Co. Ltd., China) were applied to evaluate the molecular weight of sample. $8 \%$ polyacrylamide gels were stained by Coomassie Brilliant Blue R250.

(2) Periodic Acid-Schiff Stain (PAS). The method of PAS was performed to identify the glycoprotein. The electrophoresis gel mentioned above was put in the solution of periodic acid $(2.5 \%, \mathrm{w} / \mathrm{v})$ for $2 \mathrm{~h}$ and washed using the cleaning solution (contained trichloroacetic acid of 1\%, w/v; acetic acid of $10 \%, \mathrm{v} / \mathrm{v}$ ) for $1 \mathrm{~h}$. The electrophoresis gel was stained using the Schiff reagent in dark for $2 \mathrm{~h}$ and faded using a destainer (containing potassium hydrogen sulfate of $0.1 \%$, w/v; hydrochloric acid of $2 \%, \mathrm{v} / \mathrm{v}$ ) for $12 \mathrm{~h}$.

(3) High-Performance Gel-Permeation Chromatography. The purified lectin was further verified by HP-GPC equipped with TSK gel G4000 PWXL column $(7.8 \mathrm{~mm} \times 300 \mathrm{~mm})$ and detected using a differential refraction detector (RID) (Agilent-1200, Germany) at $25^{\circ} \mathrm{C}$. The sample was dissolved in PBS solution $(20 \mathrm{mM}, \mathrm{pH} 7.2)(0.5 \mathrm{mg} / \mathrm{mL})$ at a flow rate of $0.5 \mathrm{~mL} / \mathrm{min}$, and the PBS solution $(20 \mathrm{mM}, \mathrm{pH} 7.2)$ was used as mobile phase.

2.6.2. Carbohydrate-Inhibition Assay. Different carbohydrate solutions $(25 \mu \mathrm{L})$ were two-fold serial diluted from maximum concentration $(0.4 \mathrm{M})$ in 96-well Falcon V-shaped microtiter plates, and then purified lectin solutions $(0.5 \mu \mathrm{g} / \mathrm{mL}, 25 \mu \mathrm{L})$ were added, respectively. After $1 \mathrm{~h}$ of incubation at room temperature, their hemagglutination activities were determined in accordance with the method mentioned above (Section 2.5). All the test carbohydrates (or its derivatives) were listed as follows: $\mathrm{D}$-glucose, $\mathrm{D}$-arabinose, D-fructose, L-rhamnose, D-galactose, D-xylose, D-sucrose, D-maltose, D-lactose, mannose, D-inositol, $\mathrm{N}$-acetyl-D-galactosamine, $\mathrm{N}$-acetyl-D-glucosamine, and L-fucose.

2.6.3. Metal Ion Dependence of LML. Metal ion dependence of LML was determined according to a previous report [22] with some modifications. The sample was dissolved in PBS solution $(20 \mathrm{mM}, \mathrm{pH} 7.2)$ and diluted to $62.5 \mu \mathrm{g} / \mathrm{mL}$. The solution was dialyzed ( $\mathrm{Mw}$ cut off $5 \mathrm{kDa}$ ) against PBS solution ( $20 \mathrm{mM}, \mathrm{pH} 7.2$, contained $50 \mathrm{mM}$ EDTA) at $4^{\circ} \mathrm{C}$ for $24 \mathrm{~h}$. Then, EDTA was removed from the sample solution by dialysis against PBS solution $(20 \mathrm{mM}, \mathrm{pH}$ 7.2). The hemagglutination activity of treated samples were determined before adding metal ions $(50 \mathrm{mM})$, and the corresponding metal ion solution without lectin was served as control group. All the test metal ions are listed as follows: $\mathrm{Ba}^{2+}\left(\mathrm{BaCl}_{2}\right), \mathrm{Zn}^{2+}$
$\left(\mathrm{ZnCl}_{2}\right), \mathrm{Ca}^{2+}\left(\mathrm{CaCl}_{2}\right), \mathrm{K}^{+}(\mathrm{KCl}), \mathrm{Mn}^{2+}\left(\mathrm{MnCl}_{2}\right), \mathrm{Mg}^{2+}$ $\left(\mathrm{MgCl}_{2}\right), \mathrm{Cr}^{3+}\left(\mathrm{CrCl}_{3}\right)$, and $\mathrm{Cd}^{2+}\left(\mathrm{CdCl}_{2}\right)$.

2.6.4. Effect of $p H$ on Hemagglutination Activity. The effect of $\mathrm{pH}$ on hemagglutination activity of LML was evaluated at different $\mathrm{pH}$ conditions. LML solutions $(1 \mathrm{mg} / \mathrm{mL})$ were dialyzed (Mw cut off $5 \mathrm{kDa}$ ) at $4^{\circ} \mathrm{C}$ for $24 \mathrm{~h}$ in different buffer solutions: $\mathrm{KCl}-\mathrm{HCl}(20 \mathrm{mM}, \mathrm{pH} 2.0)$, citrate-phosphate (20 mM, pH 3.0-5.0), PBS solution (20 mM, pH 6.0-7.0), Tris- $\mathrm{HCl}(20 \mathrm{mM}, \mathrm{pH} 8.0)$, glycine-sodium hydroxide (20 mM, pH 9.0-10.6), and $\mathrm{NaOH}$ solution ( $\mathrm{pH} 11.0-14.0$ ). Before further analysis, the hemagglutination activity of single buffer was carried out to eliminate the effect of buffer solutions itself. Meanwhile, the fluorescence spectrum analysis was performed to determine the structure changes of LML (Section 2.6.8).

2.6.5. Effect of Temperature and Time on Hemagglutination Activity. To determine thermal stability of LML, the sample dissolved in PBS solution $(20 \mathrm{mM}, \mathrm{pH} 7.2)(1 \mathrm{mg} / \mathrm{mL})$ was incubated at different temperatures from $25^{\circ} \mathrm{C}$ to $100^{\circ} \mathrm{C}$ and for different time periods from 0 to $10 \mathrm{~min}$ and then chilled at $4^{\circ} \mathrm{C}$. The hemagglutination activity experiment was carried out in accordance with the method mentioned above (Section 2.5).

2.6.6. Monosaccharide Composition. The monosaccharide composition analysis was performed by GC. $2 \mathrm{~mL}$ of $2.0 \mathrm{M}$ trifluoroacetic acid (TFA) was added into LML $(5 \mathrm{mg})$ and the solution was hydrolyzed at $110^{\circ} \mathrm{C}$ for $3 \mathrm{~h}$ in a sealed tube. After being completely hydrolyzed, excess TFA was removed by rotary vacuum evaporation and codistillation with methanol thrice. Hydrolyzed sample (2 mg) was mixed with hydroxylamine hydrochloride $(10 \mathrm{mg})$ and internal standard inositol $(2 \mathrm{mg})$. Then, pyridine $(0.5 \mathrm{~mL})$ was added in and reacted at $90^{\circ} \mathrm{C}$ for $30 \mathrm{~min}$. After cooling down, acetylation reaction was conducted with the addition of acetic anhydride $(0.5 \mathrm{~mL})$ at $90^{\circ} \mathrm{C}$ for $30 \mathrm{~min}$. The final product was dried by rotary evaporation and dissolved in $1 \mathrm{~mL}$ methylene chloride. Ultimately, the solution was analyzed by GC. Glucose, galactose, rhamnose, xylose, mannose, and arabinose were also derivated as standards.

2.6.7. Determination of Amino Acid Compositions. The purified sample $(2 \mathrm{mg})$ was hydrolyzed at $110^{\circ} \mathrm{C}$ for $24 \mathrm{~h}$ by adding $2 \mathrm{~mL}$ of hydrochloric acid $(6 \mathrm{M}$, included $1.5 \% 2$ mercaptoethanol) under nitrogen, and then hydrochloric acid was removed by drying in vacuum (Yide DZF-6050, China). The residuum was dissolved in hydrochloric acid $(20 \mathrm{mM})$ and centrifuged at $12,000 \times \mathrm{g}$ for $20 \mathrm{~min}$. The supernatant was collected to make a fixed volume of $50 \mathrm{~mL}$ and analyzed using an automatic amino acid analyzer (Sykam S7130, Germany).

2.6.8. Fluorescence Spectra Analysis. The sample was dissolved in PBS solution $(20 \mathrm{mM}, \mathrm{pH} 7.2)$ and diluted to 
$0.5 \mathrm{mg} / \mathrm{mL}$. Then, its fluorescence spectra were recorded in the range of 220-750 $\mathrm{nm}$ using a fluorescence photometer (Shimadzu RF-5301PC, Japan), and the slit width of emission and excitation was $5 \mathrm{~nm}$. Excitation wavelength of $292 \mathrm{~nm}$ was selected to measure the emission wavelength of test samples. And, emission wavelength of corresponding buffer solutions without samples was subtracted from all spectra.

2.6.9. Fourier-Transform Infrared Spectroscope (FT-IR) Analysis. Sample (1 mg) and $\mathrm{KBr}(150 \mathrm{mg})$ were mixed, fully ground, and tabletted. The secondary structure of lectin was analyzed using the FT-IR spectrometer (Nicolet IS50, USA). $\mathrm{KBr}$ scans were subtracted before further analysis.

2.7. Statistical Analysis. Results were expressed as means \pm standard deviation (SD), and one-factor ANOVA analysis was carried out with SPSS version 20.0 for Windows.

\section{Results and Discussion}

3.1. Purification of Lectin. As a common technique of conventional protein purification, ion-exchange chromatography was widely used for purification of lectins [23]. As depicted in Figure 1(a), four fractions including D-0 (elution volume $90-110 \mathrm{~mL}$ ), D-1(elution volume $315-350 \mathrm{~mL}$ ), D-2 (elution volume $670-675 \mathrm{~mL}$ ), and D-3 (elution volume $835-840 \mathrm{~mL}$ ) were obtained by using ion-exchange chromatography (DEAE-52), and their hemagglutination activity were measured at the same time. Except D-3, the hemagglutination activities of other fractions were extremely low and even reached zero. The activity of D-3 reached $100.79 \times 10^{3} \mathrm{HU} / \mathrm{mg}$, and its yield was $23.33 \%$ (Table 1 ). To obtain more purified lectin, D-3 was subjected to Sephadex G200 gel filtration column subsequently after dialysis and lyophilization. And, it was then eluted into three fractions (Figure 1(b)). The fraction (elution volume $40.8-45.6 \mathrm{~mL}$ ) with the highest hemagglutination activity $\left(171.12 \times 10^{3} \mathrm{HU} /\right.$ $\mathrm{mg}$ ) was collected, dialyzed, lyophilized, and termed as LML. Although the yield of LML was only $9.80 \%$, its hemagglutination activity sharply enhanced and increased by 17.37 folds compared with loach mucus powder.

\subsection{Characterization of $L M L$}

3.2.1. Identification of Purity and Molecular Weight. As shown in Figure 2(a), a single band of $245 \mathrm{kDa}$ appeared in the electrophoresis profile of LML and a corresponding aubergine band by periodic acid-Schiff stain also existed in Figure 2(b), which was a typical character of glycoprotein. Furthermore, high-performance gel-permeation chromatography profile of LML also exhibited a single intense peak (retention time at $6.867 \mathrm{~min}$ ) with molecular weight to be $245.40 \mathrm{kDa}$ (Figure 3 ). The result indicated the purity of LML was qualified, and the difference between the result of SDSPAGE and HP-GPC might be induced by the shape of protein molecules [24]. The molecular weight of LML was similar to those reported in Indian catfish lectin $(200 \mathrm{kDa})$, bighead crap lectin $(220 \mathrm{kDa})$, and loach skin mucus lectin $(300 \mathrm{kDa}$ with two subunits of $41 \mathrm{kDa}$ and $40 \mathrm{kDa}$ ) $[9,25,26]$, but was larger than those in zebrafish lectin $(14.5 \mathrm{kDa})$, crap egg lectin $(26.6 \mathrm{kDa})$, conger eel lectin (congerin II, $15.3 \mathrm{kDa})$, and Cyclina sinensis lectin $(72 \mathrm{kDa})$ [27-30].

3.2.2. Carbohydrate-Specific Binding and Metal Dependence. Lectin was a kind of protein or glycoprotein that could be specifically recognized by noncovalent binding carbohydrates due to the structure of CRD [12]. As with LML, the hemagglutination activity was inhibited by D-glucose, D-arabinose, D-galactose, D-xylose, D-lactose, mannitol, $\mathrm{N}$-acetyl-D-galactosamine, $\mathrm{N}$-acetyl-D-glucosamine, and L-fucose, and their minimum concentrations are shown in Table 2. Other tested carbohydrates were not detected having inhibitory activity at the concentration tested. Besides, LML entirely lost hemagglutination activity after dialysis against EDTA solution and recovered most part of hemagglutination activity on incubation with $\mathrm{Ca}^{2+}$. This phenomenon suggested LML was a kind of metalloprotein, and $\mathrm{Ca}^{2+}$ played an important role in the function and structure of LML [31]. A previous study reported that a part of lectins need metal ion to maintain their structure and activity. For instance, $\mathrm{Ca}^{2+}$ - and $\mathrm{Mn}^{2+}$-binding sites existed in legume lectins [32]. Although metal ions existing in legume lectins did not interact directly with the bound carbohydrate, they could be helpful to fold into its functional conformation and quaternary structure [33].

\subsubsection{LML Activity at Various $p H$ Values and Temperatures.} Figure 4(a) suggested the hemagglutination activity of LML was very low when $\mathrm{pH}$ lowered than 6.0, indicating its capacity of acid resistance was weak. The maximum hemagglutination activity was maintained at $\mathrm{pH} 7.5-8.5$, whereas its hemagglutination activity gradually decreased at $\mathrm{pH}$ beyond 8.5. However, the lectin kept about 30\% hemagglutination activity even at $\mathrm{pH} 14$. This result indicated LML had a strong ability of alkali resistance, but its capacity of acid resistance was weak. Besides, the maximum hemagglutination activity of LML was obtained at $25^{\circ} \mathrm{C}$ to $50^{\circ} \mathrm{C}$. When the temperature was higher than $50^{\circ} \mathrm{C}$, the hemagglutination activity of LML decreased and was depended on treating temperature and time (Figure 4(b)). After LML reacted at $85^{\circ} \mathrm{C}$ for $6 \mathrm{~min}$, its activity was entirely lost. Heat endurance of different lectins also varied. For example, Tritrichomonas foetus lectin entirely lost activity at $80^{\circ} \mathrm{C}$ for 30 min [20], whereas Entamoeba histolytica lectin lost approximately $75 \%$ of hemagglutination activity even stored at $4^{\circ} \mathrm{C}$ overnight [34].

3.2.4. Structure Change at Different $p H$ Values. LML mixed with PBS solution $(20 \mathrm{mM}, \mathrm{pH} 7.2)$ was used as the native lectin sample, and the maximum emission wavelength at $337 \mathrm{~nm}$ was detected at excitation wavelength of $292 \mathrm{~nm}$ (Figure 5(a)). Tyrosine's characteristic peak at $303 \mathrm{~nm}$ was not detected when the excitation wavelength was set as 


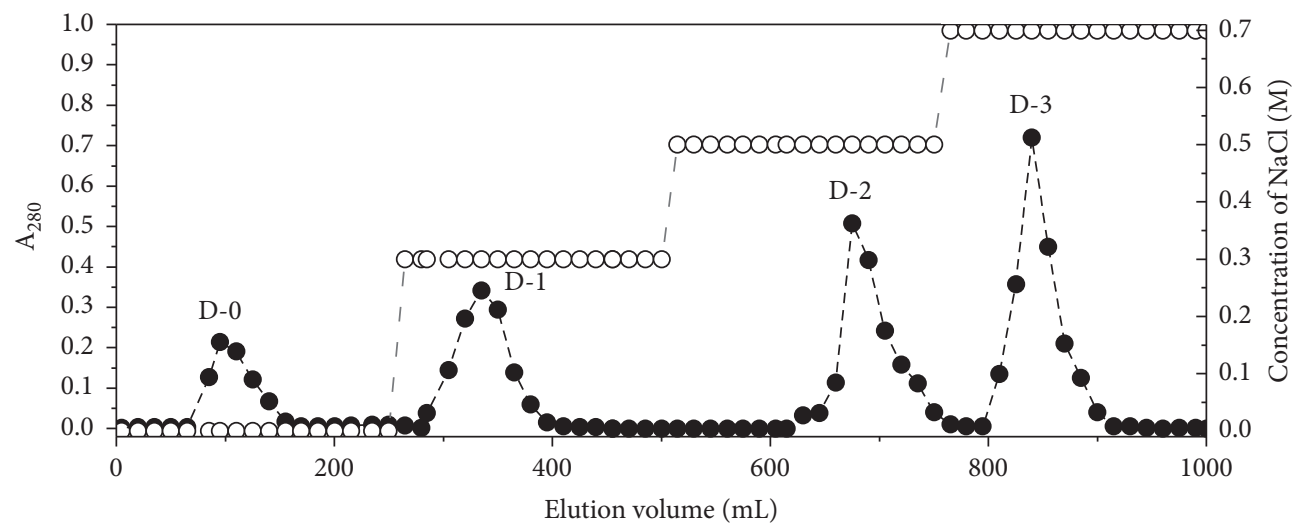

(a)

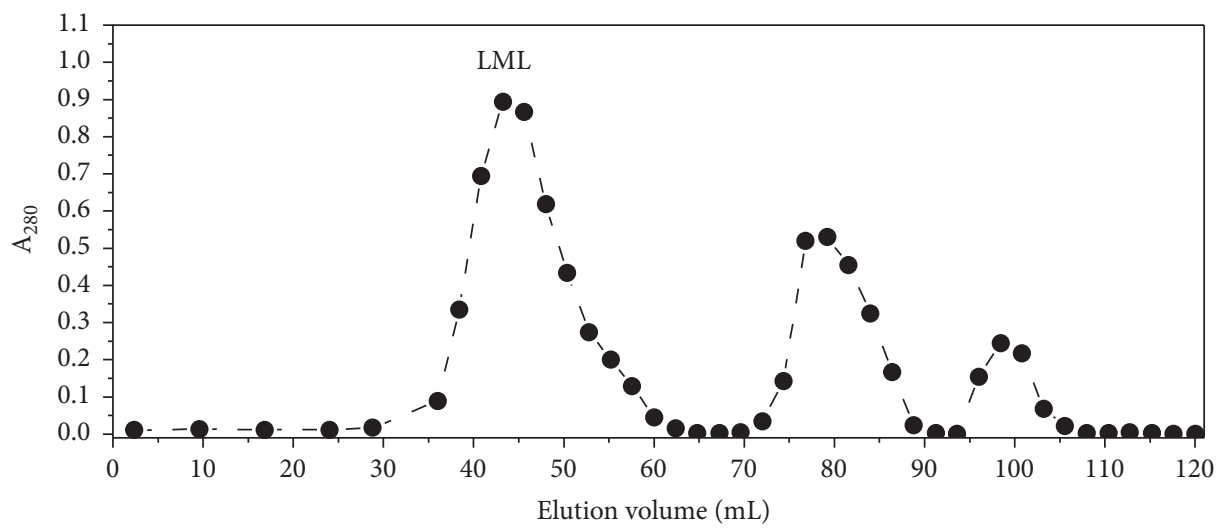

(b)

Figure 1: (a) Purification of lectin from loach skin mucus by DEAE-52: the four fractions (D-0, D-1, D-2, and D-3) were eluted by 0 (PBS, $20 \mathrm{mM}, \mathrm{pH}$ 7.2), 0.3, 0.5, and $0.7 \mathrm{M} \cdot \mathrm{NaCl}$ solution (mixed with PBS, $20 \mathrm{mM}, \mathrm{pH} 7.2$ ) at a flow rate of $1 \mathrm{~mL} / \mathrm{min}$, respectively; (b) purification of D-3 by Sephadex G200: the three fractions were eluted using PBS $(20 \mathrm{mM}, \mathrm{pH} 7.2)$ solution at a flow rate of $0.3 \mathrm{~mL} / \mathrm{min}$.

TABLE 1: Extraction and purification of loach mucus lectin.

\begin{tabular}{lccccc}
\hline & Protein percentage (\%) & $\begin{array}{c}\text { Carbohydrate } \\
\text { percentage (\%) }\end{array}$ & Yield (\%) & Hemagglutination activity $\left(\times 10^{3}\right.$ HU/mg) & Purification fold (folds) \\
\hline Mucus powder & 36.95 & 4.46 & 100 & 9.57 & 1 \\
Crude extract & 53.50 & 4.82 & 35.13 & 11.97 & 1.25 \\
D-3 & 71.28 & 3.67 & 23.33 & 100.79 & 8.42 \\
LML & 94.77 & 2.75 & 9.80 & 166.23 & 17.37 \\
\hline
\end{tabular}

$280 \mathrm{~nm}$, which suggested energy transformation from the excited tyrosine to tryptophan emerged [35]. And, compared with characteristic peak of emission wavelength of free tryptophan $(348 \mathrm{~nm})$, obvious blue shift of $11 \mathrm{~nm}$ was recorded. This phenomenon was because tryptophan residues may locate in the hydrophobic areas of LML [36].

Figure 5(b) suggested the change of emission spectra peak at different $\mathrm{pH}$. The maximum emission wavelength showed a downward trend at $\mathrm{pH}$ from 7.0 to 5.5. A previous report indicated that acidic condition would lead to the modification of amino acid such as tryptophan residue and result in the transformation of tryptophan location from hydrophellolic areas to hydrophobic areas [36, 37]. However, when the $\mathrm{pH}$ value changed from $\mathrm{pH} 5.5$ to 2.0, the red shift of $14 \mathrm{~nm}$ was recorded, which approved that the tryptophan residue was exposed in hydrophellolic areas and protein structure was gradually unfolded. Furthermore, the maximum emission wavelength exhibited irregular fluctuation when the $\mathrm{pH}$ value ranged from 7.0 to 14.0 , which suggested hydrophobicity of active center became weak instead of entire destruction [38].

3.2.5. Monosaccharide Composition Analysis. LML was a kind of natural glycoprotein with low carbohydrate content $(2.75 \%)$. And, its carbohydrate chain was composed of rhamnose, arabinose, xylose, mannose, glucose, and galactose with a molar ratio of $2.02: 11.66: 2.06: 1.00: 14.09: 6.00$ 


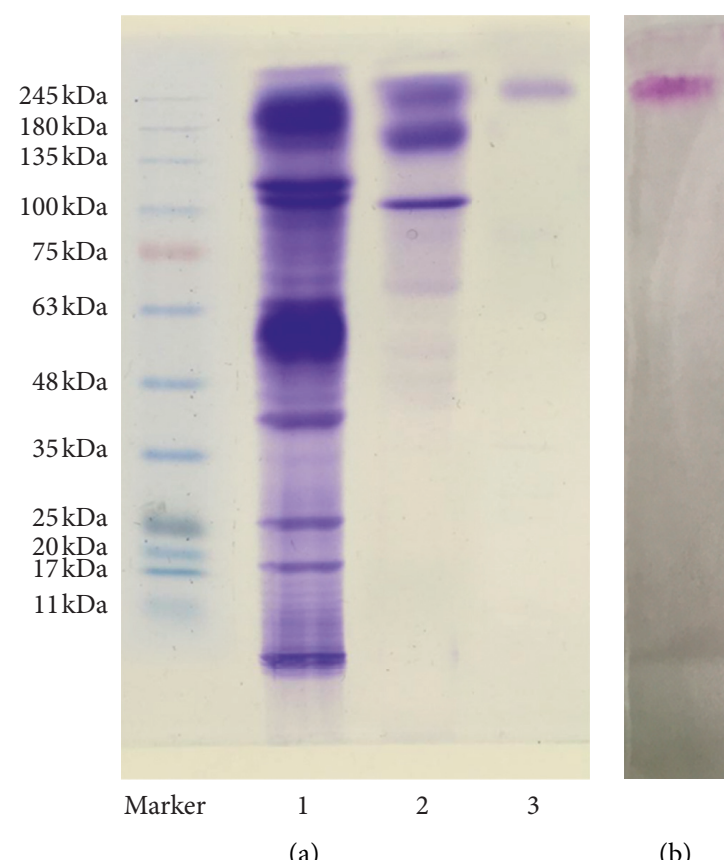

FIGURE 2: (a) Purity and molecular weight of LML by SDS-PAGE: lane markers: rainbow prestained markers (11 kDa-245 kDa); lane 1: crude extract, $2.5 \mathrm{mg} / \mathrm{mL}, 20 \mu \mathrm{L}$; lane 2: D-3 obtained by DEAE-52 ion-exchange chromatography, $1.4 \mathrm{mg} / \mathrm{mL}, 20 \mu \mathrm{L}$; lane 3: LML obtained by Sephadex G200 gel filtration chromatography, $1.0 \mathrm{mg} / \mathrm{mL}, 20 \mu \mathrm{L}$. (b) The electrophoretogram of LML by periodic acid-Schiff stain, $1.0 \mathrm{mg} /$ $\mathrm{mL}, 20 \mu \mathrm{L}$.

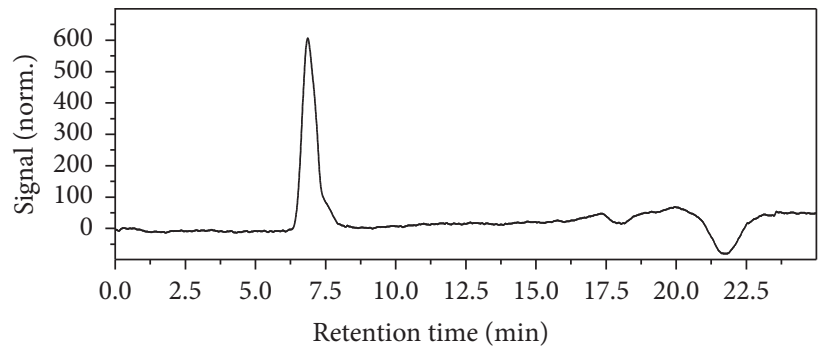

(a)

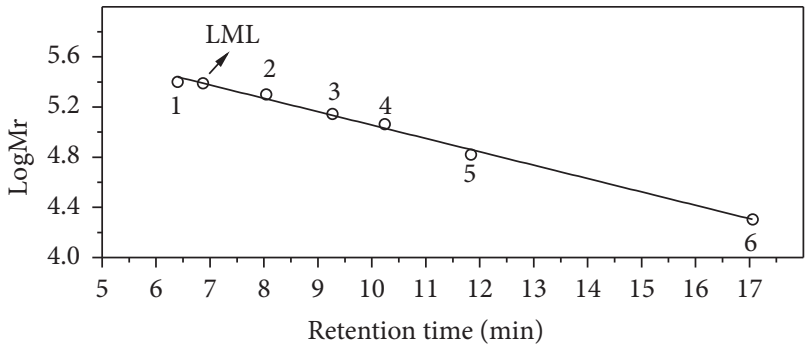

(b)

FIGURE 3: HP-GPC chromatogram of LML (a) and standard curve (b). Retention time of the standard reference proteins was plotted against the log molecular weight, and standards were as follows: 1 , catalase $(250 \mathrm{kDa}) ; 2$, myosin $(200 \mathrm{kDa}) ; 3$, lactic dehydrogenase (140 kDa); 4 , $\beta$-galactosidase $(116 \mathrm{kDa}) ; 5$, bovine serum albumin $(66 \mathrm{kDa}) ; 6$, trypsin inhibitor $(20.1 \mathrm{kDa})$.

TABLE 2: Inhibition of hemagglutination activity of the LML by different carbohydrates.

\begin{tabular}{lc}
\hline Carbohydrates (or its derivatives) & $\begin{array}{c}\text { Minimum inhibitory } \\
\text { concentration }(\mathrm{mM})\end{array}$ \\
\hline D-Glucose & 200 \\
D-Arabinose & 50 \\
D-Galactose & 3.0 \\
D-Xylose & 50 \\
D-Lactose & 0.78 \\
Mannitol & 50 \\
N-Acetyl-D-galactosamine & 50 \\
N-Acetyl-D-glucosamine & 200 \\
L-Fsucose & 50 \\
\hline
\end{tabular}

(Figure 6). Therefore, glucose, arabinose, and galactose were the major monosaccharides of LML. And, the content of mannose was the lowest in six tested monosaccharides. A previous study reported that MAL, a kind of lectin from loach skin mucus, contained galactose (13.6\%), mannose $(2.1 \%)$, and xylose $(2.5 \%)$. But, rhamnose, arabinose, and glucose were not reported in lectin of MAL-1 [9].

3.2.6. Analysis of Amino Acid Compositions. The result of amino acid composition in LML was obtained (Table 3), indicating the major amino acid constituents were glutamic acid, serine, histidine, and lysine, respectively, followed by 


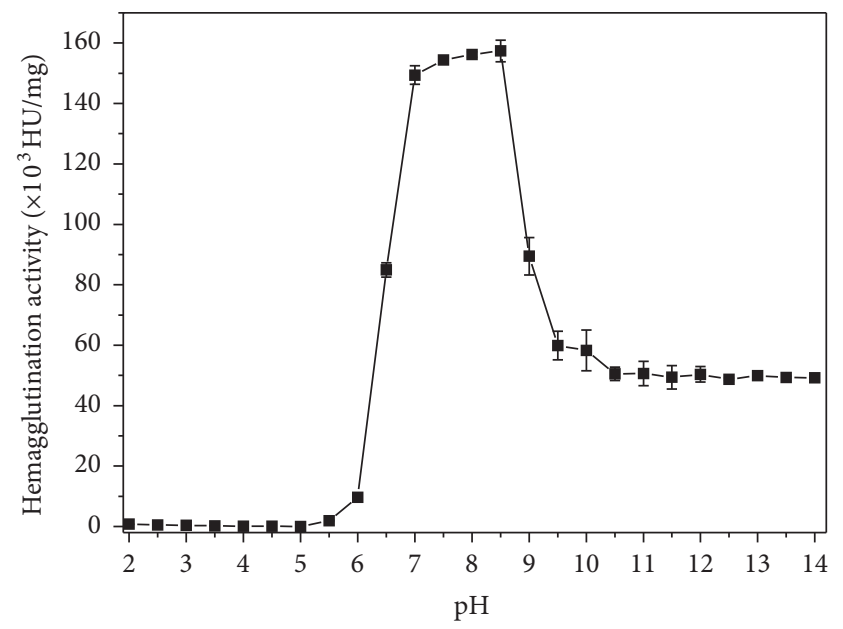

(a)

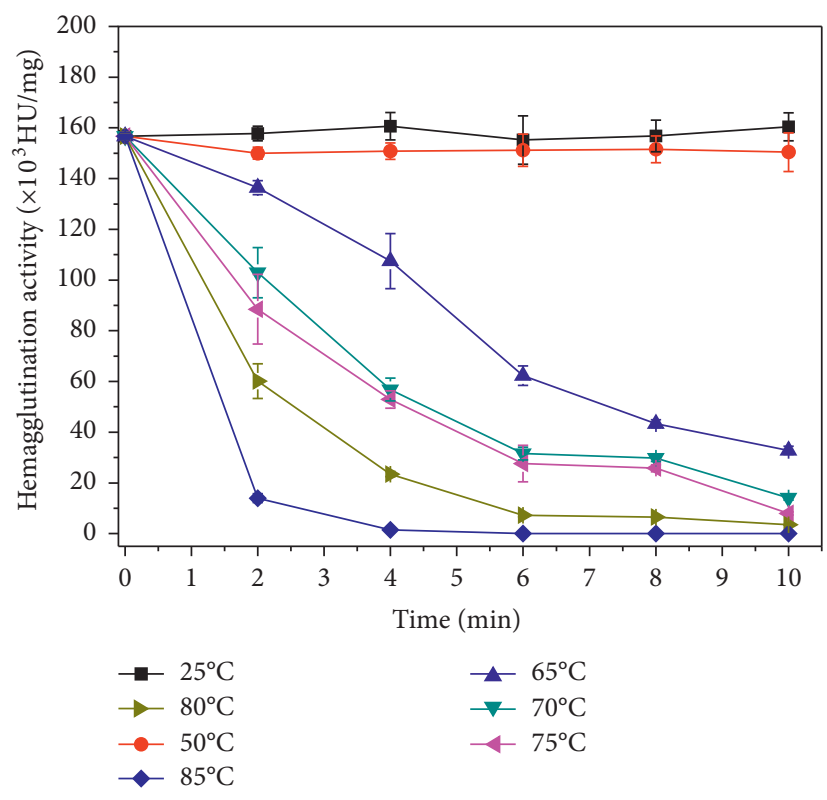

(b)

FIGURE 4: Effect of $\mathrm{pH}$ (a) and temperature (b) on hemagglutination activity of LML.

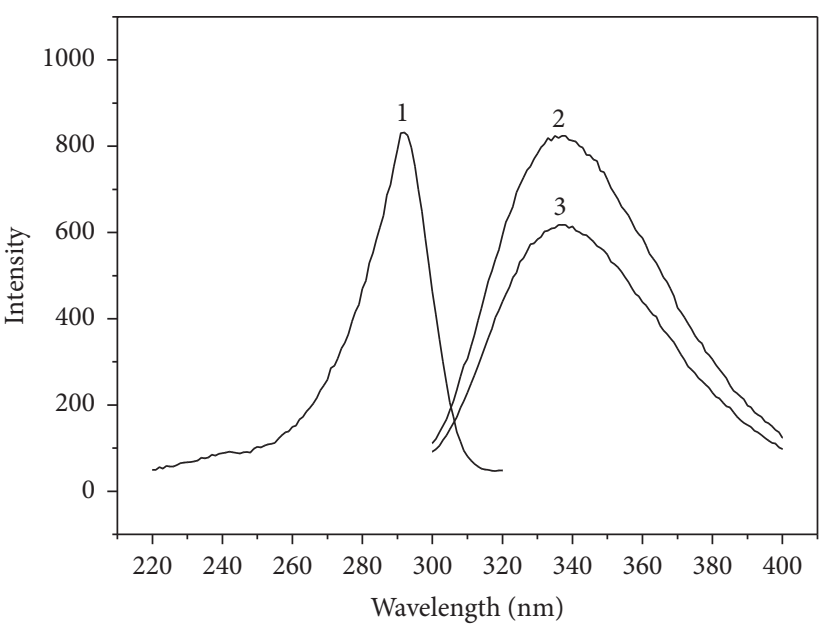

(a)

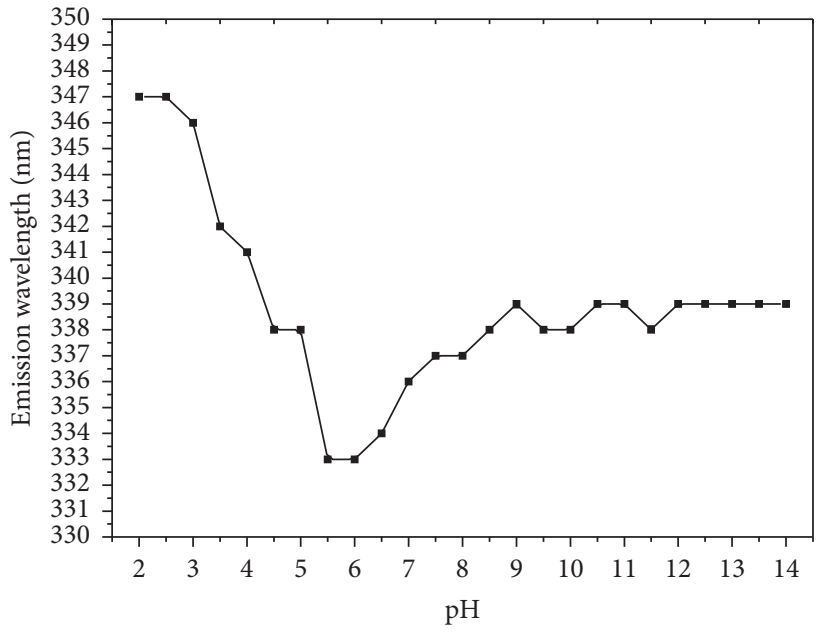

(b)

FiguRE 5: (a) Fluorescence spectra of native LML: curve 1 is excitation spectrum at emission wavelength of $337 \mathrm{~nm}$; curves 2 and 3 are emission spectra at excitation wavelengths of $280 \mathrm{~nm}$ and $292 \mathrm{~nm}$, respectively. Slit width of emission and excitation was $5 \mathrm{~nm}$; and (b) the change of emission spectra peak using the excitation wavelength of $292 \mathrm{~nm}$ and the slit width of emission and excitation was $5 \mathrm{~nm}$.

relatively abundant amino acid (valine, leucine, proline, tryptophan, and glycine). The amino acid compositions of extremely small percentages were cysteine, aspartate, tyrosine, and isoleucine. Three other types of amino acids (including threonine, methionine, and arginine) were not detected, which was different from previous reports on lectin of loach skin mucus [9]. Besides, asparagin was not analyzed in LML-3-I because high temperature and concentration of hydrochloric acid could result in hydrolysis of asparagin to aspartic acid and ammonia [39]. Similarly, glutamine could be hydrolyzed to glutamic acid and ammonia [40] at the concentration of strong hydrochloric acid.

3.2.7. FT-IR Analysis. FT-IR spectrum is a useful method to determine the type of functional group and the secondary structure of protein. Usually, hydrogen bonds forming between the carbonyl and amide group are primary force for maintaining the secondary structure of protein, and FT-IR is a kind of powerful technology to study hydrogen bonds [41]. 


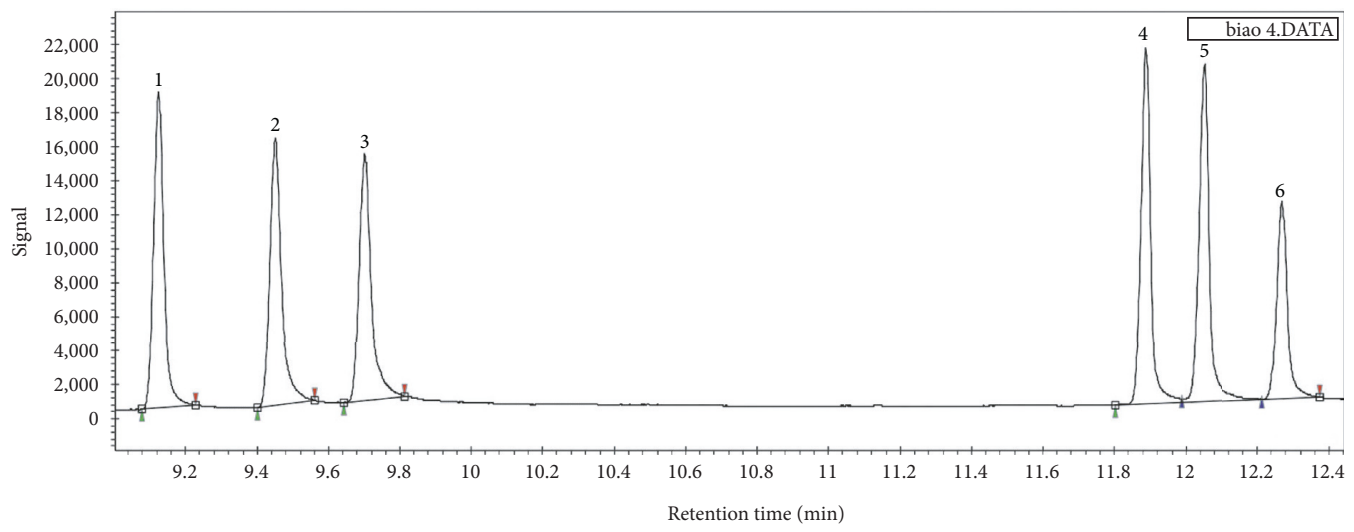

(a)

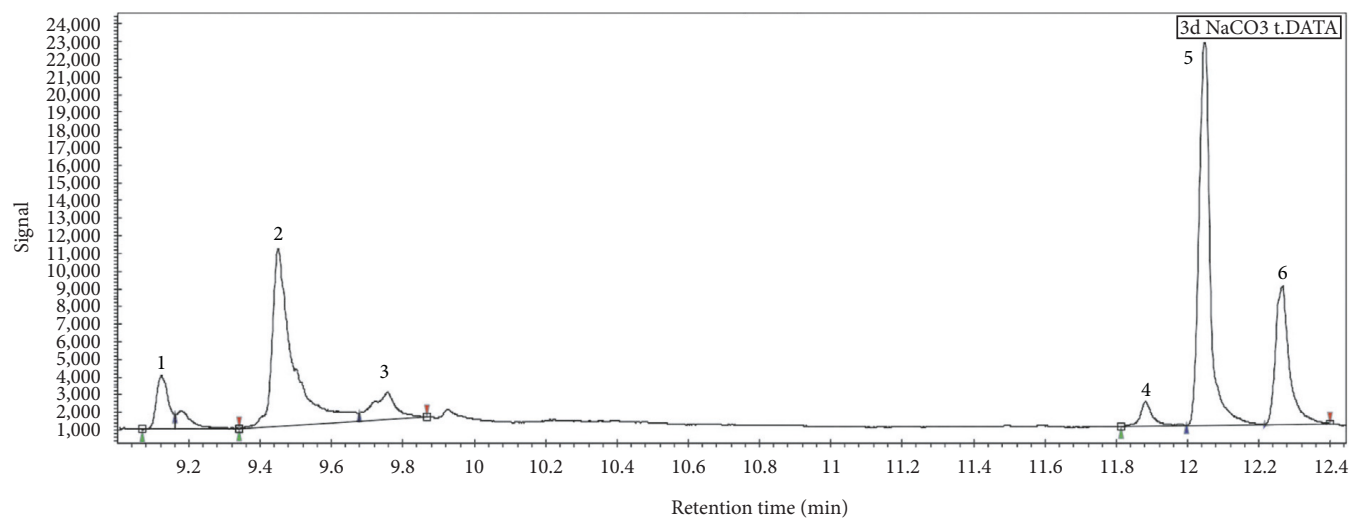

(b)

FIgURE 6: Monosaccharide standard (a) and monosaccharide composition of LML (b) (the peaks represent rhamnose (1), arabinose (2), xylose (3), mannose (4), glucose (5), and galactose (6) in the above figure).

Table 3: Amino acid composition of LML.

\begin{tabular}{lc}
\hline Amino acid & Mol\% \\
\hline Aspartate & 1.89 \\
Threonine & n.d. \\
Serine & 10.33 \\
Glutamic acid & 17.91 \\
Proline & 7.09 \\
Glycine & 6.82 \\
Alanine & 4.54 \\
Valine & 7.92 \\
Methionine & n. d. \\
Cysteine & 0.70 \\
Isoleucine & 2.26 \\
Leucine & 7.33 \\
Tyrosine & 3.67 \\
Phenylalanine & 3.79 \\
Tryptophan & 6.95 \\
Histidine & 9.57 \\
Lysine & 9.23 \\
Arginine & n.d. \\
\hline
\end{tabular}

"n.d." represents that the amino acid was not detected.

Therefore, the FT-IR spectrum of LML was measured (Figure $7(\mathrm{a})$ ). The strong and wide absorption band at $3388.75 \mathrm{~cm}^{-1}$ was the characteristic absorption band of protein, attributed to the superposition between $\mathrm{O}-\mathrm{H}$ and
$\mathrm{N}-\mathrm{H}$ stretching vibration, which suggested the existence of intramolecular hydrogen bonds, intermolecular hydrogen bonds, and amidogen in LML. The three absorption bands at $3000-2850 \mathrm{~cm}^{-1}$ indicated asymmetric stretching vibration of methyl $\left(-\mathrm{CH}_{3}\right)$, asymmetric stretching vibration of methylene $\left(=\mathrm{CH}_{2}\right)$, and symmetrical stretching vibration of methyl $\left(-\mathrm{CH}_{3}\right)$, respectively. The absorption band at $1651.64 \mathrm{~cm}^{-1}$ (amide I band) and 1536.44 (amide II band) $\mathrm{cm}^{-1}$ were important characteristic absorption bands of protein, which indicated $\mathrm{C}=\mathrm{O}$ stretching vibration, $\mathrm{C}-\mathrm{N}$ stretching vibration, and $\mathrm{N}-\mathrm{H}$ stretching vibration, respectively. The three absorption bands at $1500-1300 \mathrm{~cm}^{-1}$ were triggered by the bending vibration of $\mathrm{C}-\mathrm{H}$, and two absorption bands at $1026-1152 \mathrm{~cm}^{-1}$ suggested the existence of pyranose [42]. Besides, $\alpha$-type glycosidic linkage in the LML was revealed by the absorption band at $879.22 \mathrm{~cm}^{-1}$ [43]. Moreover, the potential secondary structure information in amide I was further analyzed, and curve-fitting spectra were obtained by fitting multipeak function of origin 8.0. The results of curve-fitting spectra are shown in Figure 7(b) and Table 4. The three bands at frequency regions from $1618 \mathrm{~cm}^{-1}$ to $1640 \mathrm{~cm}^{-1}(1618,1619$, and $1632 \mathrm{~cm}^{-1}$, respectively) were assigned to $\beta$-sheet [44], accounting for $27.55 \%$. Peaks of $1641 \mathrm{~cm}^{-1}$ and $1648 \mathrm{~cm}^{-1}$ could be assigned to unordered structure, and similar assignments were reported in the secondary structure of 


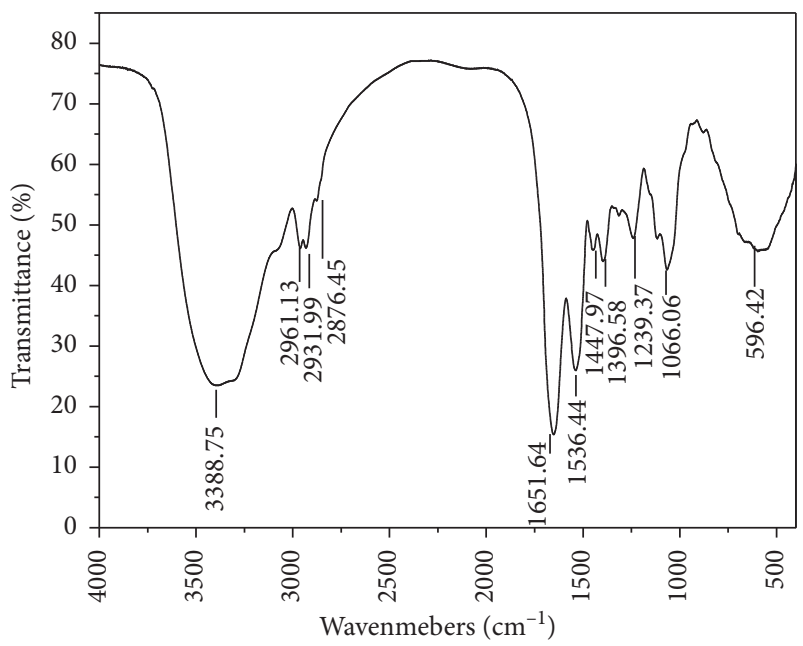

(a)

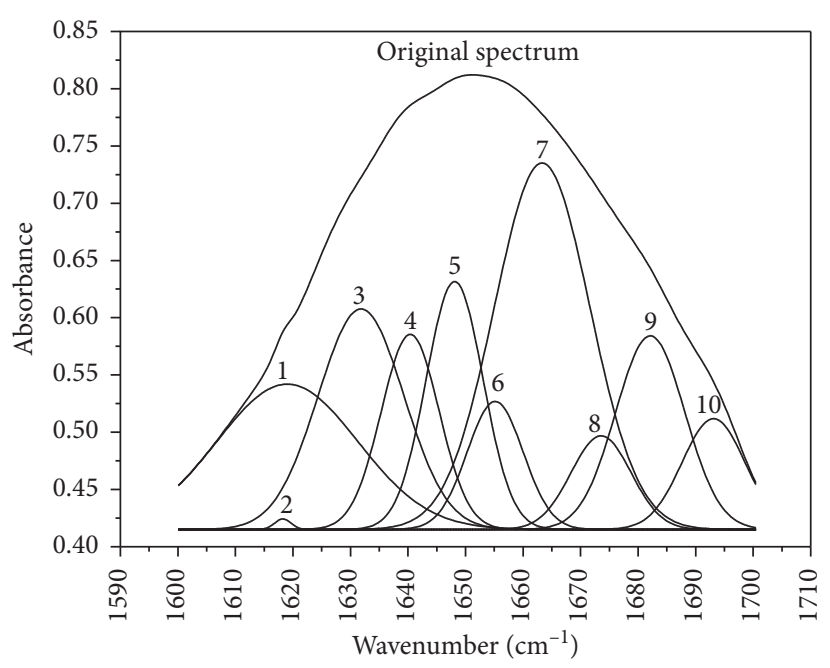

(b)

FIgURE 7: (a) FT-IR spectra of LML and (b) original spectrum and curve fitting spectra of amide I for LML.

TABLE 4: The assignments of curve-fitting spectra and secondary structural ratio for LML.

\begin{tabular}{lcccc}
\hline Number & $\begin{array}{c}\text { Wavenumber } \\
\left(\mathrm{cm}^{-1}\right)\end{array}$ & Area & Assignments & Percentage (\%) \\
\hline 1 & 1618.24 & 0.03 & & \\
2 & 1619.01 & 3.9 & $\beta$-sheet & 27.55 \\
3 & 1631.84 & 3.6 & & \\
4 & 1640.39 & 2.15 & Unordered & 17.70 \\
5 & 1648.11 & 2.69 & & 4.97 \\
6 & 1655.16 & 1.36 & $\alpha$-Helix & \\
7 & 1663.31 & 8.67 & & \\
8 & 1673.56 & 1.07 & turns & 49.78 \\
9 & 1682.11 & 2.55 & & \\
10 & 1693.11 & 1.32 & & \\
\hline
\end{tabular}

lysozyme [45, 46]. Unordered structure accounted for $17.70 \%$ in LML. The $\alpha$-helix absorption accounting for $4.97 \%$ appeared at $1655 \mathrm{~cm}^{-1}$ [47]. The strong band at a frequency of $1663.31 \mathrm{~cm}^{-1}$ was assigned to turns structure, and similar bands were detected in ribonuclease $S$ [45]. Some weak bands at $1674 \mathrm{~cm}^{-1}, 1682 \mathrm{~cm}^{-1}$, and $1693 \mathrm{~cm}^{-1}$ were also assigned to turn structure [48], and thus all of the turn structures accounted for $49.78 \%$.

\section{Conclusion}

In this paper, a new kind of lectin (LML) with a molecular weight of $245 \mathrm{kDa}$ from loach skin mucus was successfully isolated and purified. Its hemagglutination could be inhibited by D-lactose and required the presence of $\mathrm{Ca}^{2+}$. It was stable in extensive alkaline buffer solution. Moreover, the structure of LML was partially characterized, and results indicated that its carbohydrate chain was composed of rhamnose, arabinose, xylose, mannose, glucose, and galactose. Amino acid analysis suggested it contained abundant glutamic acid, histidine, and serine. The secondary structure of LML mainly contained turns structure. The potent hemagglutination activity of LML could be developed into a health-care product or else, which would provide new insight into comprehensive utilization of skin mucus from loach and lay foundation for its application in food industry. Also, further studies focusing on its bioactivity mechanism and structure-activity relationship would be worthy to conduct in the future.

\section{Data Availability}

The data used to support the findings of this study are included within the article.

\section{Conflicts of Interest}

The authors declare no potential conflicts of interest.

\section{Acknowledgments}

The authors acknowledge the financial support from the projects provided by Tianjin Municipal Science and Technology Bureau (Contract nos.: 17ZXYENC00140, 18JCTPJC56700, and BDCXY2017016) and Tianjin $\mathrm{Mu}-$ nicipal Agricultural and Rural Commission (Contract nos.: 201801170 and 201704080). Besides, the authors are grateful to the financial support from the project titled "Prepared freshwater fish dishes and nutritional soups processing technology and industrialized application" provided by Baodi District Science and Technology Bureau of Tianjin.

\section{References}

[1] Y. Wang, M. Hu, W. Wang, S. G. Cheung, P. K. S. Shin, and L. Cao, "Effects of the timing of initial feeding on growth and survival of loach (Misgurnus anguillicaudatus) larvae," Aquaculture International, vol. 18, no. 2, pp. 135-148, 2010.

[2] C. Zhang and K. Huang, "Mechanism of apoptosis induced by a polysaccharide, from the loach Misgurnus anguillicaudatus 
(MAP) in human hepatocellular carcinoma cells," Toxicology and Applied Pharmacology, vol. 210, no. 3, pp. 236-245, 2006.

[3] X. Z. Dong, H. B. Xu, K. X. Huang, Q. Liou, and J. Zhou, "The preparation and characterization of an antimicrobial polypeptide from the loach, Misgurnus anguillicaudatus," Protein Expression and Purification, vol. 26, no. 2, pp. 235-242, 2002.

[4] Z. H. Sun, J. J. Wang, X. L. Hou, and Z. R. Zhang, "Preparation and characterization of hyaluronic acid from mucilage of loach," Pharmaceutical Biotechnology, vol. 8, pp. 42-44, 2001.

[5] C. G. Qin, K. X. Huang, and H. B. Xu, "Bioactive molecules in the loach and their pharmacological actions," Chinese Journal of Biochemical Pharmaceutics, vol. 23, pp. 47-48, 2002.

[6] G. A. Ingram, "Substances involved in the natural resistance of fish to infection-a review," Journal of Fish Biology, vol. 16, no. 1, pp. 23-60, 1980.

[7] M. S. Liang, Y. Liu, Y. Zhen, and H. Q. Wan, "The discovery of superoxide dismutase from the slime of the cutaneous covering of Misgurus anguillicaudatus," Southwest China Journal of Agricultural Sciences, vol. 12, pp. 120-121, 1999.

[8] M. Kimura, Y. Hama, T. Sumi et al., "Characterization of adeaminated neuraminic acid-containing glycoprotein from the skin mucus of the loach, Misgurnus anguillicaudatus," The Journal of Biological Chemistry, vol. 269, pp. 32138-32143, 1994.

[9] R. Goto-Nance, Y. Watanabe, H. Kamiya, and H. Ida, "Characterization of lectins feom the skin mucus of the lonach, Misgurnus anguillicaudatus," Fisheries Science, vol. 61, no. 1, pp. 137-140, 1995.

[10] C. G. Qin, K. X. Huang, and H. B. Xu, "Protective effect of polysaccharide from the loach on the in vitro and in vivo peroxidative damage of hepatocyte," The Journal of Nutritional Biochemistry, vol. 13, no. 10, pp. 592-597, 2002.

[11] Y. Suzuki, S. Tasumi, S. Tsutsui, M. Okamoto, and H. Suetake, "Molecular diversity of skin mucus lectins in fish," Comparative Biochemistry and Physiology Part B: Biochemistry and Molecular Biology, vol. 136, no. 4, pp. 723-730, 2003.

[12] R. S. Singh, A. K. Walia, and J. F. Kennedy, "Structural aspects and biomedical applications of microfungal lectins," International Journal of Biological Macromolecules, vol. 134, pp. 1097-1107, 2019.

[13] S. H. Loh, J. Y. Park, E. H. Cao, S. Y. Nah, and Y. S. Kang, "Animal lectins: potential receptors for ginseng polysaccharides," Journal of Ginseng Research, vol. 41, no. 1, pp. 1-9, 2017.

[14] L. L. Juan, V. G. Recio, P. J. Lopez, T. G. Juan, M. CordobaDiaz, and D. Cordoba-Diaz, "Pharmaceutical applications of lectins," Journal of Drug Delivery Science and Technology, vol. 42, pp. 126-133, 2017.

[15] G. Vandenborre, G. Smagghe, and E. J. M. Van Damme, "Plant lectins as defense proteins against phytophagous insects," Phytochemistry, vol. 72, no. 13, pp. 1538-1550, 2011.

[16] S. A. Alen'kina, V. A. Bogatyrev, L. Y. Matora et al., "Signal effects of the lectin from the associative nitrogen-fixing bacterium Azospirillum brasilense Sp7 in bacterial-plant root interactions," Plant and Soil, vol. 381, no. 1-2, pp. 1-13, 2014.

[17] R. S. Singh, A. K. Walia, and J. R. Kanwar, "Protozoa lectins and their role in host-pathogen interactions," Biotechnology Advances, vol. 34, no. 5, pp. 1018-1029, 2016.

[18] M. M. Bradford, "A rapid and sensitive method for the quantitation of microgram quantities of protein utilizing the principle of protein-dye binding," Analytical Biochemistry, vol. 72, no. 1-2, pp. 248-254, 1976.

[19] M. Dubois, K. A. Gilles, J. K. Hamilton, P. A. Rebers, and F. Smith, "Colorimetric method for determination of sugars and related substances," Analytical Chemistry, vol. 28, no. 3, pp. 350-356, 1956.

[20] P. Babal, F. F. Pindak, L. C. Russell, and W. A. Gardner, "Sialic acid-specific lectin from Tritrichomonas foetus," Biochimica et Biophysica Acta (BBA)-General Subjects, vol. 1428, no. 1, pp. 106-116, 1999.

[21] U. K. Laemmli, "Cleavage of structural proteins during the assembly of the head of bacteriophage T4," Nature, vol. 227, no. 5259, pp. 680-685, 1970.

[22] R. B. Costa, P. T. Campana, F. S. Chambergo et al., "Purification and characterization of a lectin with refolding ability from Genipa americana bark," International Journal of Biological Macromolecules, vol. 119, pp. 517-523, 2018.

[23] R. Cagliari, F. S. Kremer, and L. da Silva Pinto, "Bauhinia lectins: biochemical properties and biotechnological applications," International Journal of Biological Macromolecules, vol. 119, pp. 811-820, 2018.

[24] Y. Kong, W. T. Wu, and R. J. Wu, "Comparision of methods for analysis of methyl mercury and the preparation of methyl mercury reference," Analytical Instrumentation, vol. 2, pp. 44-46, 2003.

[25] S. Dutta, B. Sinha, B. Bhattacharya, B. Chatterjee, and S. Mazumder, "Characterization of a galactose binding serum lectin from the Indian catfish, Clarias batrachus: possible involvement of fish lectins in differential recognition of pathogens," Comparative Biochemistry and Physiology Part C: Toxicology \& Pharmacology, vol. 141, no. 1, pp. 76-84, 2005.

[26] T. B. Ng, R. C. F. Cheung, C. C. W. Ng, E. F. Fang, and J. H. Wong, "A review of fish lectins," Current Protein \& Peptide Science, vol. 16, no. 4, pp. 337-351, 2015.

[27] H. Ahmed, S. J. Du, N. O'Leary, and G. R. Vasta, "Biochemical and molecular characterization of galectins from zebrafish (Danio rerio): notochord-specific expression of a prototype galectin during early embryogenesis," Glycobiology, vol. 14, no. 3, pp. 219-232, 2004.

[28] M. Galliano, L. Minchiotti, M. Campagnoli et al., "Structural and biochemical characterization of a new type of lectin isolated from carp eggs," Biochemical Journal, vol. 376, no. 2, pp. 433-440, 2003.

[29] K. Muramoto, D. Kagawa, T. Sato, T. Ogawa, Y. Nishida, and H. Kamiya, "Functional and structural characterization of multiple galectins from the skin mucus of conger eel, Conger myriaster," Comparative Biochemistry and Physiology Part B: Biochemistry and Molecular Biology, vol. 123, no. 1, pp. 33-45, 1999.

[30] C. Q. Tong, W. Li, L. Kong et al., “A novel yeast-binding lectin from hemolymph Cyclina sinensis (Gmelin) and its effects on yeast cells," Process Biochemistry, vol. 47, no. 12, pp. 21662171, 2012.

[31] R. S. Singh, A. K. Walia, and J. F. Kennedy, "Purification and characterization of a mitogenic lectin from Penicillium duclauxii," International Journal of Biological Macromolecules, vol. 116, pp. 426-433, 2018.

[32] R. Loris, "Principles of structures of animal and plant lectins," Biochimica et Biophysica Acta (BBA)-General Subjects, vol. 1572, no. 2-3, pp. 198-208, 2002.

[33] S. Kaushik, D. Mohanty, and A. Surolia, "The role of metal ions in substrate recognition and stability of concanavalin A: a molecular dynamics study," Biophysical Journal, vol. 96, no. 1, pp. 21-34, 2009.

[34] D. Kobiler and D. Mirelman, "Lectin activity in Entamoeba histolytica trophozoites," Infection and Immunity, vol. 29, no. 1, pp. 221-225, 1980. 
[35] C. Liu, S. F. Wang, Y. J. Yang, Z. Liang, and D. H. Wan, "Study on the optical properties of a lectin from Lycopersicon esculentum," Journal of Anhui Agricultural Sciences, vol. 36, pp. 401-403, 2008.

[36] N. Devyani and R. Mala, "Structural and functional role of tryptophan in xylanase from an extremophilic Bacillus: assessment of the active site," Biochemical and Biophysical Research Communications, vol. 249, no. 1, pp. 207-212, 1998.

[37] H. Kawagishi and H. Mori, "Chemical modification and NMR studies on a mushroom lectin Ischnoderma resinosum agglutinin (IRA)," Biochimica et Biophysica Acta (BBA)-Protein Structure and Molecular Enzymology, vol. 1076, no. 2, pp. 179-186, 1991.

[38] S. D. He, J. Shi, Y. Ma, S. J. Xue, H. W. Zhang, and S. X. Zhao, "Kinetics for the thermal stability of lectin from black turtle bean," Journal of Food Engineering, vol. 142, pp. 132-137, 2014.

[39] I. Kusumoto, "Industrial production of L-glutamine," The Journal of Nutrition, vol. 131, no. 9, pp. 2552S-2555S, 2001.

[40] P. E. Wilcox, "Determination of amide residues by chemical methods," in Methods in Enzymology, vol. 11, pp. 63-67, Elsevier, Amsterdam, Netherlands, 1967.

[41] M. Jackson and H. H. Mantsch, "The use and misuse of FTIR spectroscopy in the determination of protein structure," Critical Reviews in Biochemistry and Molecular Biology, vol. 30, no. 2, pp. 95-120, 1995.

[42] Z. Y. Zhu, M. Meng, H. Q. Sun, Y. Li, and Y.-M. Zhang, "Structural analysis and immunostimulatory activity of glycopeptides from Paecilomyces sinensis," Food \& Function, vol. 7, no. 3, pp. 1593-1600, 2016.

[43] E. Wiercigroch, E. Szafraniec, K. Czamara et al., "Raman and infrared spectroscopy of carbohydrates: a review," Spectrochimica Acta Part A: Molecular and Biomolecular Spectroscopy, vol. 185, pp. 317-335, 2017.

[44] J. A. Hering and P. I. Haris, "FTIR spectroscopy for analysis of protein secondary structure," Spectroscopy and Spectral Analysis, vol. 31, pp. 1786-1789, 2011.

[45] D. M. Byler and H. Susi, "Examination of the secondary structure of proteins by deconvolved FTIR spectra," Biopolymers, vol. 25, no. 3, pp. 469-487, 1986.

[46] A. Sakudo, H. Kuratsune, Y. Hakariya Kato, and K. Ikuta, "Secondary structural changes of proteins in fingernails of chronic fatigue syndrome patients from Fourier-transform infrared spectra," Clinica Chimica Acta, vol. 402, no. 1-2, pp. 75-78, 2009.

[47] M. Carbonaro, P. Maselli, P. Dore, and A. Nucara, "Application of Fourier transform infrared spectroscopy to legume seed flour analysis," Food Chemistry, vol. 108, no. 1, pp. 361-368, 2008.

[48] X. Y. Chen, Y. Ru, F. L. Chen, X. C. Wang, X. Y. Zhao, and Q. Ao, "FTIR spectroscopic characterization of soy proteins obtained through AOT reverse micelles," Food Hydrocolloids, vol. 31, no. 2, pp. 435-437, 2013. 

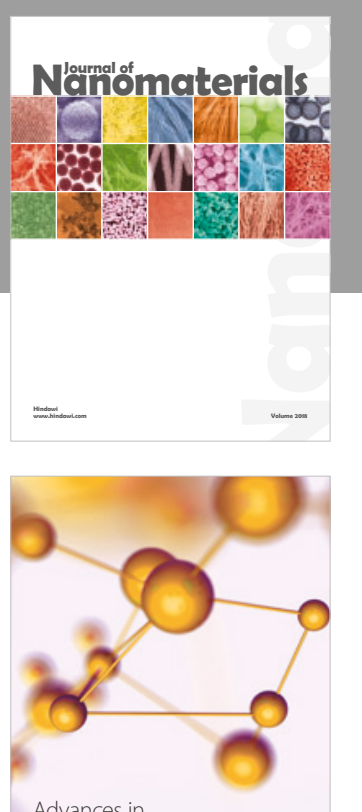

Physical Chemistry
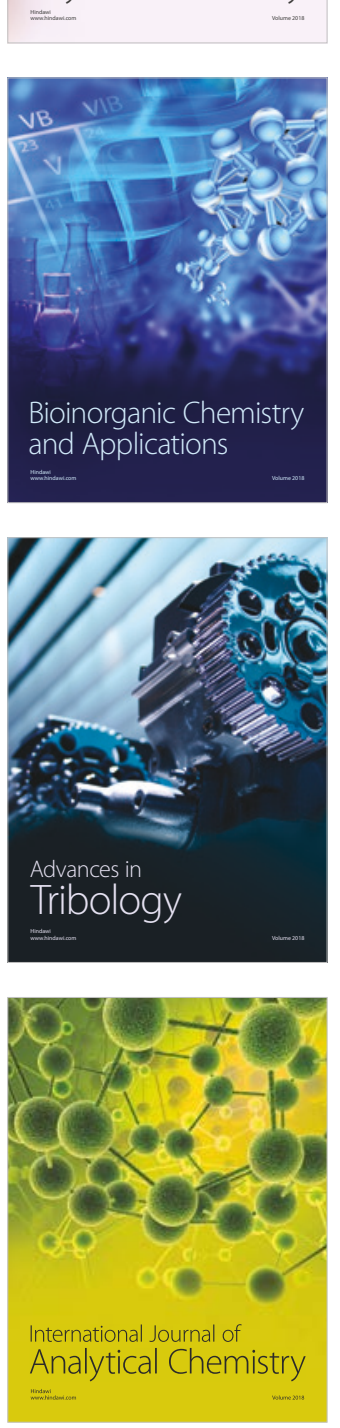

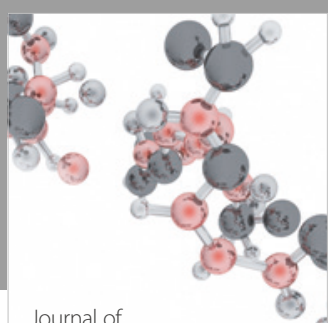

Analytical Methods

in Chemistry

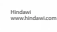

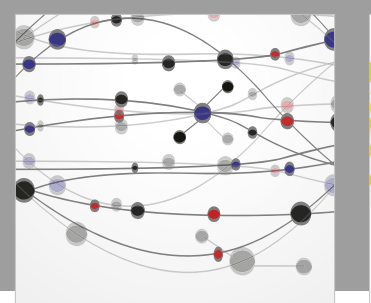

The Scientific World Journal

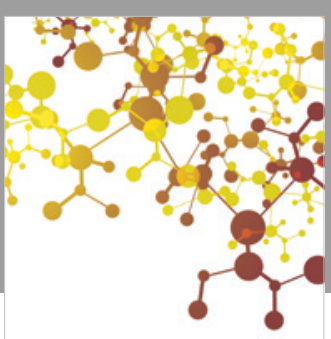

Journal of

Applied Chemistry
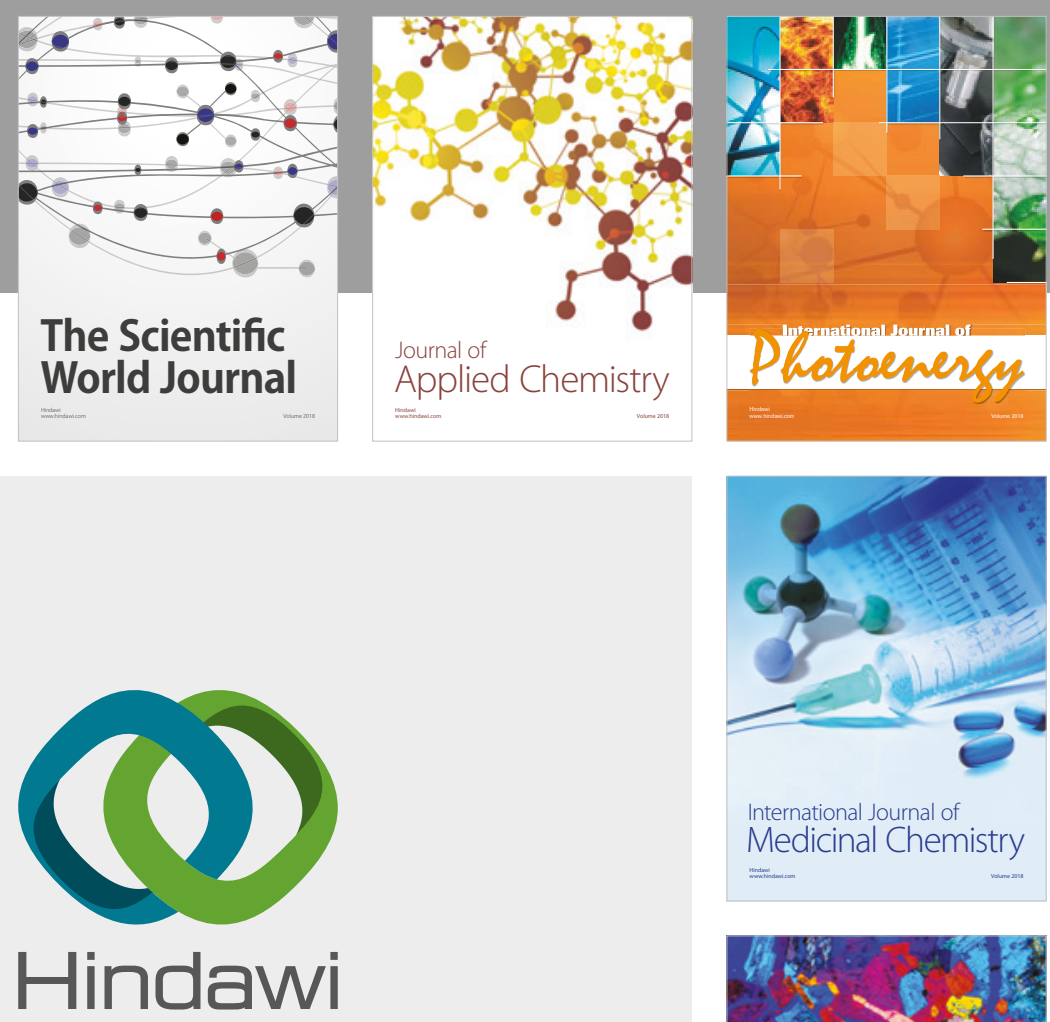

Submit your manuscripts at

www.hindawi.com
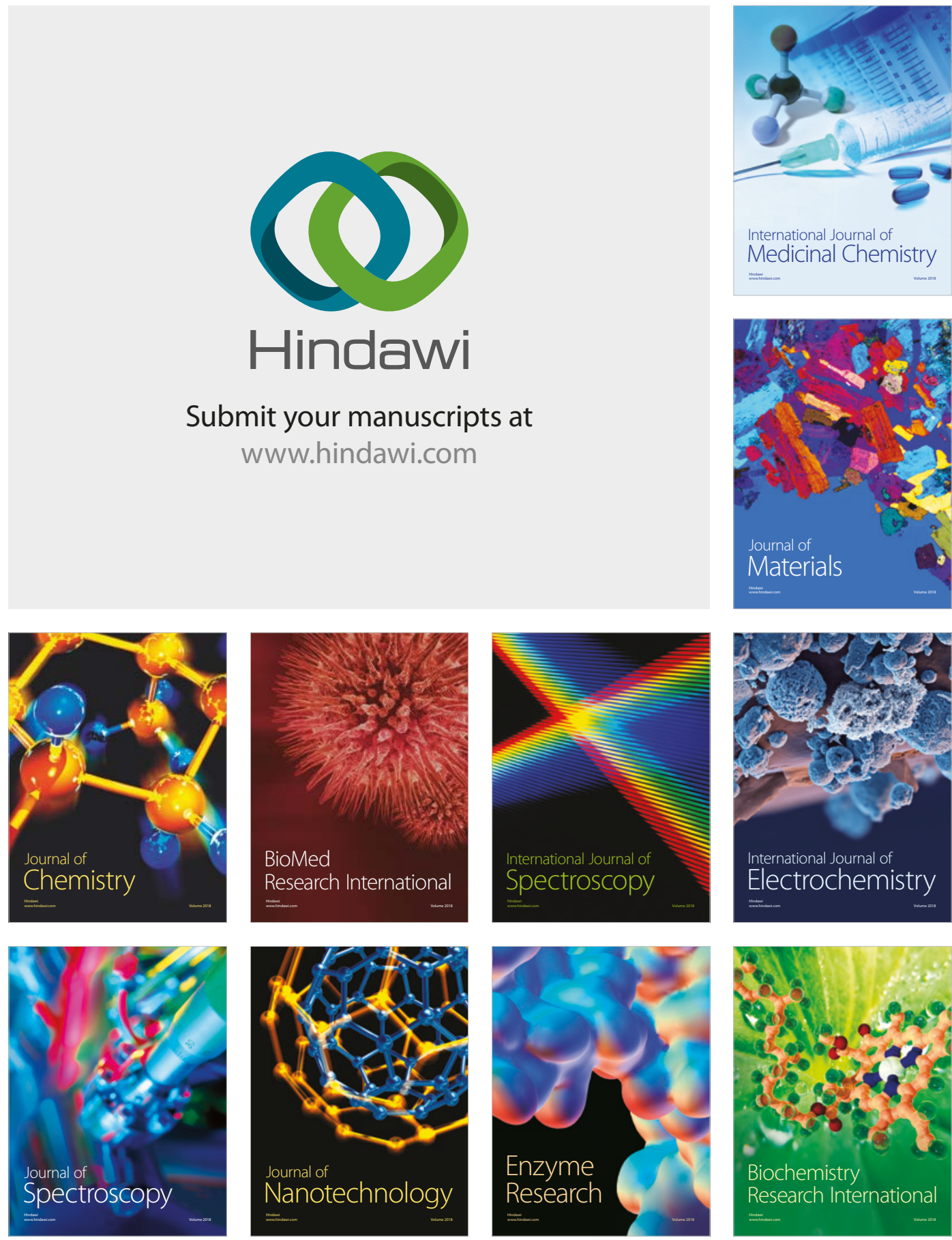
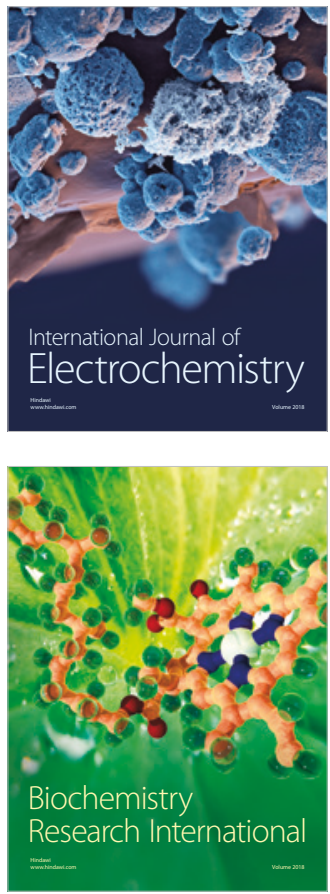